\title{
Citra Tubuh pada Remaja Pengguna Instagram
}

\author{
Era Kurnia Aristantya ${ }^{1} \mathcal{E}$ Avin Fadilla Helmi ${ }^{2}$ \\ 1,2Fakultas Psikologi Universitas Gadjah Mada
}

\begin{abstract}
Adolescents are active social media user. There are various interactions that happen in social media, social support is one of them. In Instagram, the interaction between users can be giving likes, comments, and sending direct messages. Meanwhile, high school adolescents (15-18 years old) have high preoccupation toward their body image. Thus, online social support is considered to have relationship with body image in adolescents Instagram's user. The purpose of this research was to examine the relationship between online social support and adolescent's body image. The subjects of this research were adolecents who lived in DI Yogyakarta, DKI Jakarta, Bandung, and Surabaya $(n=235)$. Body image was measured using MBSRQ-AS (The Multidimensional Body-Self Relations Questionnaire-Appearance Scales) and online social support was measured using Social Support in Social Media Scale. The result of product moment analysis showed that online social support significantly correlated with adolescent's body image $(r=0.261 ; p<0.05)$. Further analysis found that there was body image difference between male and female adolescents $(t=-2.104 ; p<0.05)$. Age, location, access period, and the type of account followed did not have significant role on body image. In conclusion, adolescents need to have positive peer support.
\end{abstract}

Keywords: adolescent; body image; instagram; online social support

Abstrak. Remaja merupakan pengguna aktif media sosial. Bentuk interaksi dalam media sosial dapat bermacam-macam. Salah satunya dalam bentuk dukungan sosial. Dalam media sosial Instagram, interaksi antarpengguna dapat berupa likes, komentar, dan direct message. Sementara itu, remaja usia SMA (15 sampai 18 tahun) memiliki perhatian yang tinggi terhadap citra tubuhnya. Dukungan sosial online dianggap memiliki hubungan dengan citra tubuh remaja pengguna media sosial Instagram. Tujuan penelitian ini untuk menguji hubungan antara dukungan sosial online dengan citra tubuh remaja. Subjek penelitian mencakup remaja dari empat wilayah, yaitu DI Yogyakarta, DKI Jakarta, Bandung, dan Surabaya $(n=235)$. Citra tubuh diukur menggunakan skala MBSRQ-AS dan dukungan sosial online diukur menggunakan Skala Dukungan Sosial dalam Jejaring Sosial. Analisis dengan teknik korelasi product moment menunjukkan hasil signifikan $(r=0,261 ; p<0,05)$. Analisis tambahan menemukan perbedaan citra tubuh antara remaja laki-laki dan perempuan $(t=-2,104 ; p<0,05)$. Usia, domisili, indeks masa tubuh, lama akses, dan jenis akun yang diikuti tidak berperan signifikan terhadap citra tubuh.

Kata kunci: citra tubuh; dukungan sosial online; instagram; remaja

Remaja merupakan individu yang mengalami pertumbuhan dan perkem-

${ }^{1}$ Korespondensi mengenai artikel ini dapat dilakukan melalui eraristantya@gmail.com

ªtau avinpsi@ugm.ac.id bangan pada berbagai aspek, diantaranya aspek fisik, kognitif, dan sosioemosional (Santrock, 2011). Pada aspek fisik, remaja memiliki ketertarikan terhadap tampilan fisik. Hal itu disebabkan oleh terjadinya 
pubertas pada awal perkembangan remaja yang mengakibatkan adanya perubahan fisik. Selain aspek fisik yang sangat terlihat perubahannya, aspek penting lain dalam masa remaja yaitu aspek sosioemosional. Perkembangan aspek sosioemosional remaja dipengaruhi oleh lingkungan sosialnya. Lingkungan sosial (social environment) adalah individu lain atau kelompok yang ada di luar diri seperti keluarga, teman, tetangga, atau secara umum disebut dengan masyarakat tempat individu berinteraksi. Selain perubahan lingkungan sosial, terjadi perubahan penggunaan media oleh remaja (Santrock, 2011). Remaja memanfaatkan internet, terutama media sosial, untuk berinteraksi secara online dengan lingkungan sosialnya. Lingkungan sosial di sekitar remaja dapat menjadi sumber suatu bentuk hubungan sosial yang menguntungkan, yaitu dukungan sosial. Dukungan sosial adalah hubungan dengan lingkungan sekitar yang untuk memenuhi kebutuhan baik secara psikologis, fisik, maupun kebutuhan yang bersifat material (Mattson \& Hall, 2011).

Terdapat keterkaitan antar aspek fisik dan aspek emosional dalam perkembangan remaja. Pada umumnya, remaja ingin menampilkan dirinya sebaik mungkin karena sangat memperhatikan penampilan fisik. Namun, ketertarikan terhadap tampilan fisik dapat memicu adanya perbandingan penampilan baik dengan orang lain di sekitarnya maupun dengan figur-figur tubuh ideal yang sering ditampilkan di media. Menurut Fox \& Vendernia (2016) perbandingan penampilan memiliki implikasi pada kesejahteraan psikologis dan fisik individu karena akan menimbulkan ketidakpuasan tubuh (body dissatisfaction). Dibandingkan remaja laki-laki, umumnya remaja perempuan lebih tidak puas terhadap citra tubuh mereka ketika masa pubertas (Santrock, 2011). Ketidakpuasan terhadap tubuh berkaitan dengan citra tubuh (body image) individu. Citra tubuh adalah kepuasan atau ketidakpuasan individu terhadap gambaran tubuhnya (Cobb, 2007). Oleh karena itu, remaja dirasa membutuhkan dukungan dari lingkungan sosialnya untuk meningkatkan kondisi psikologis terkait ketidakpuasan terhadap citra tubuh mereka. Dukungan sosial dapat membantu individu yang sedang mengalami tekanan agar memiliki perasaan yang lebih positif mengenai dirinya.

Lingkungan sosial dapat menjadi sumber dukungan sosial bagi remaja, akan tetapi, lingkungan sosial terutama teman sebaya juga dapat mendorong remaja mengikuti bentuk tubuh ideal yang dapat ditemukan di berbagai media (Fox \& Vendernia, 2016). Terlebih lagi, pada zaman sekarang yang telah dibanjiri oleh berbagai media sosial. Di dalam media sosial banyak konten yang berisikan figur ideal yang diidamkan para remaja. Mereka pada umumnya telah menggunakan media sosial sebagai sarana berinteraksi, mencari informasi, dan mencari hiburan. Berbagai contoh jenis media sosial yang populer antara lain Facebook, Twitter, Path, YouTube, Instagram, dan Pinterest. Masing-masing media sosial tersebut memiliki keunggulan dan spesifikasi kegunaan yang berbeda.

Salah satu media sosial yang sedang populer di dunia dan banyak digunakan oleh remaja adalah Instagram. Instagram merupakan media sosial yang menggunakan foto atau video sebagai bentuk komunikasi. Interaksi di dalam Instagram adalah dengan menjadi pengikut (followers) akun pengguna Instagram lain. Interaksi dengan akunakun yang tidak di-private pun dapat dilakukan tanpa harus menjadi followers. Komunikasi dalam Instagram diwakilkan 
dengan memberi tanda suka (like) dan memberi komentar pada foto atau video yang telah diunggah oleh pengguna lain (Ridgway \& Clayton, 2016). Foto yang diunggah pada Instagram biasanya diubah agar mendapatkan lebih banyak likes dari pengguna Instagram lain. Banyaknya likes merupakan indikator bahwa foto atau video, atau pesan yang diunggah merupakan hal yang menarik perhatian orang lain (Tyler, 2016). Bahkan, penelitian pada remaja perempuan menunjukkan bahwa likes dan jumlah followers dihubungkan dengan penghargaan orang lain terhadap tampilan fisik mereka dan dapat meningkatkan penghargaan diri (Chua \& Chang, 2016).

Kepopuleran Instagram kemudian dimanfaatkan untuk media iklan dan promosi yang menyebabkan kemunculan selebgram (selebritis Instagram). Tidak sedikit jumlah selebgram yang menampilkan figur tubuh ideal sehingga muncul istilah 'body goals' yang merujuk pada instensi untuk membuat bentuk tubuh serupa dengan target yang disebut sebagai 'body goals'. Fenomena selebgram yang populer dengan tubuh langsing nan indah membuat pengguna Instagram, terutama perempuan mengalami ketidakpuasan terhadap tubuh mereka (body dissatifaction), kecemasan terkait berat badan, dan gangguan makan (Harper \& Tiggemann, 2008; Morry \& Staska, 2001; Murnen, Smolak, Mills, \& Good, 2003 dalam Ghaznavi \& Taylor, 2015). Selain itu, sebuah penelitian yang dilakukan oleh Brown dan Tiggemann (2016) menyatakan bahwa paparan gambar selebriti dengan tubuh ideal dan menarik dapat merusak citra tubuh (body image) individu tersebut. Selain menurunkan citra tubuh, gambargambar yang menunjukkan sosok 'tubuh ideal' dapat menyebabkan peningkatan suasana hati (mood) negatif dan menurunkan harga diri (self-esteem).
Dampak negatif dari paparan tubuh ideal tersebut merupakan risiko dari interaksi dalam media sosial. Namun, terdapat suatu bentuk hubungan sosial atau hubungan interpersonal yang saling menguntungkan untuk melawan dampak negatif dari penggunaan media sosial agar tidak menjadi stressor dalam kehidupan seorang remaja yang sangat memperhatikan penampilan fisik. Bentuk interaksi yang menguntungkan tersebut disebut dukungan sosial. Dukungan sosial merujuk pada kenyamanan, perhatian, penghargaan, atau bantuan yang diterima seseorang dari orang lain, seperti: pasangan, keluarga, teman, atau komunitas (Tajalli, Sobhi, \& Ganbaripanah, 2010). Dukungan sosial yang positif dapat menguatkan remaja dalam menjalani kehidupan sehari-hari yang penuh tantangan. Terlebih lagi saat memasuki masa remaja, individu menghabiskan waktu lebih banyak dengan teman sebaya daripada keluarganya (Krcmar, Giles \& Helsne, 2008 dalam Cash \& Smolak, 2011). Bagi remaja, diterima oleh teman sebayanya merupakan suatu kebutuhan (Santrock, 2011). Oleh karena itu, teman sebaya menjadi salah satu sumber dukungan sosial yang dibutuhkan dalam menjalani proses dan dinamika masa remaja.

Internet, terutama media sosial, dapat menjadi wadah bagi individu untuk menyatakan dukungan sosial. Hal tersebut disebabkan media sosial terutama Instagram menyediakan sarana interaksi seperti yang telah dijelaskan sebelumnya yaitu berupa likes, komentar, dan direct message (DM). Definisi dukungan sosial online adalah dukungan yang diberikan individu satu kepada individu lain melalui situs jejaring sosial, dukungan yang diberikan dapat berupa kata-kata atau komentar maupun respon lain terhadap sesuatu yang ditulis dan 
ditampilkan seseorang dalam jejaring sosial (Suryani, 2014).

Konsep dukungan sosial didukung oleh penelitian dengan metode studi literatur mengenai remaja yang menemukan sebuah kesimpulan bahwa dukungan sosial dari teman dapat menurunkan tingkat ketidakpuasan tubuh dan meningkatkan citra tubuh yang positif (Ata, Ludden, \& Lally, 2007; Bearman, Martinez, \& Stice, 2006; Stice, Presnell, \& Spangler, 2002 dalam Webb \& Zimmer-Gembeck, 2014). Namun sebaliknya, terdapat penelitian pada subjek mahasiswa (dewasa awal) yang dilakukan oleh Asberg dan Wagaman (2010) yang menyatakan bahwa justru tidak ada hubungan yang signifikan antara dukungan sosial dan citra tubuh. Perbedaan penemuan mengenai hubungan dukungan sosial dan citra tubuh tersebut kemudian menimbulkan ketertarikan peneliti untuk mencari tahu lebih lanjut apakah hasil penelitian akan berbeda jika dilakukan pada remaja Indonesia yang menggunakan Instagram. Peneliti menyempitkan dukungan sosial hanya pada dukungan sosial online karena dalam konteks pengguna media sosial Instagram. Peneliti merumuskan hipotesis bahwa semakin tinggi tingkat dukungan sosial online pada remaja, maka semakin tinggi pula citra tubuh remaja yang menggunakan media sosial, terutama Instagram.

\section{Metode}

\section{Partisipan penelitian}

Partisipan dalam penelitian ini adalah remaja yang berdomisili di wilayah Daerah Istimewa Yogyakarta, DKI Jakarta, Bandung, dan Surabaya, berjenis kelamin laki-laki dan perempuan dengan rentang usia 15-18 tahun. Jumlah total subjek dalam penelitian ini adalah 235 orang dari empat wilayah dengan proporsi 67 orang $(28,5 \%)$ berjenis kelamin laki-laki dan 168 orang $(71,5 \%)$ adalah perempuan. Dalam penelitian ini, dukungan sosial online adalah variabel independen dan citra tubuh adalah variabel dependen.

\section{Instrumen penelitian}

Pengumpulan data dalam penelitian ini menggunakan skala. Terdapat dua skala yang digunakan dalam penelitian ini. Pertama, skala citra tubuh Multidimensional Body-Self Relations Questionnarie-Appearance Scale (MBRSQAS) disusun oleh Cash dan telah diadaptasi oleh Kurniawan (2014). MBSRQ-AS memiliki lima subskala yaitu : 1) evaluasi penampilan, 2) orientasi penampilan, 3) kepuasan area tubuh, 4) kecemasan kegemukan, dan 5) pengategorian ukuran tubuh. Analisis uji coba terhadap 150 remaja usia SMA (1518 tahun) menunjukkan bahwa Skala Citra Tubuh (MBSRQ-AS) dengan 34 aitem terdapat 6 aitem yang tidak memenuhi batas koefisien korelasi aitem total. Keenam aitem tersebut digugurkan sehingga tersisa 28 aitem dan menghasilkan koefisien reliabilitas alpha berstrata sebesar 0,804 .

Skala yang kedua yang digunakan adalah skala Dukungan Sosial dalam Jejaring Sosial milik Fitriani (2014) yang diadaptasi oleh Suryani (2014). Skala tersebut terdiri dari tiga aspek yang terdapat dalam 19 aitem yaitu aspek dukungan emosional, dukungan penghargaan, dan dukungan informasi. Pengumpulan data dilakukan secara online dengan bantuan kuesioner online Google Form. Koefisien reliabilitas alpha Cronbach alat ukur ini menunjukkan nilai 0,909 berdasarkan uji coba terhadap 150 remaja usia SMA (15-18 tahun).

\section{Analisis data}

Metode analisis yang digunakan dalam penelitian ini adalah analisis korelasi 
product moment. Peneliti juga melakukan analisis tambahan. Untuk mengetahui perbedaan citra tubuh pada remaja lakilaki dan perempuan dilakukan t-test. Analisis varians (ANOVA) dilakukan untuk mengetahui peran usia, domisili, indeks masa tubuh, lama waktu akses internet dan Instagram, serta jenis akun yang diikuti terhadap citra tubuh remaja.

\section{Hasil}

Hipotesis yang diajukan akan diuji dengan menggunakan teknik korelasi product moment Pearson untuk menemukan hubungan antara variabel bebas dan variabel tergantung. Melalui uji korelasi product moment pada variabel citra tubuh dan variabel dukungan sosial online didapatkan hasil $r=0,261$ dengan nilai
Rendahnya sumbangan efektif dukungan sosial online terhadap citra tubuh disebabkan oleh dukungan sosial online tidak memiliki hubungan dengan semua dimensi citra tubuh. Analisis interkorelasi menunjukkan bahwa dukungan sosial online hanya memiliki korelasi dengan dua dimensi citra tubuh, yaitu dimensi orientasi penampilan $(r=$ 0,294, $p<0,01$ ) dan dimensi kecemasan kegemukan $(r=0,159, p<0,05)$ yang dijabarkan dalam Tabel 1.

Hasil analisis tambahan pada faktor jenis kelamin menggunakan t-test menunjukkan nilai $t=-2,104$ dengan signifikansi 0,036 $(p<0,05)$. Dari hasil tersebut diketahui bahwa ada perbedaan citra tubuh remaja ditinjau dari jenis kelamin. Rerata citra tubuh pada remaja perempuan lebih tinggi dibandingkan

Tabel 1.

Korelasi Variabel Independen dengan Dimensi Variabel Dependen

\begin{tabular}{lc}
\hline \multicolumn{1}{c}{ Dimensi Variabel Citra Tubuh } & Variabel Dukungan Sosial Online \\
\hline Dimensi evaluasi penampilan & $0,075(p>0,05)$ \\
Dimensi orientasi penampilan & $\underline{0,294(p<0,01)}$ \\
Dimensi kepuasan area tubuh & $0,051(p>0,05)$ \\
$\underline{\text { Dimensi kecemasan kegemukan }}$ & $\underline{0,159(p<0,05)}$ \\
Dimensi pengategorisasian ukuran tubuh & $0,001(p>0,05)$ \\
\hline
\end{tabular}

signifikansi 0,000 $(p<0,01)$. Berdasarkan hasil tersebut, dapat dikatakan terdapat hubungan positif yang signifikan antara variabel citra tubuh dengan variabel dukungan sosial online. Hubungan positif menunjukkan bahwa semakin tinggi dukungan sosial online, maka akan semakin tinggi citra tubuh individu. Koefisien korelasi $r=0,261$ memiliki koefisien determinan ( $R$-squared) sebesar 0,068 . Hal ini menunjukkan hubungan variabel citra tubuh dengan dukungan sosial online memberikan sumbangan efektif sebesar 0,068 atau $6,8 \%$ terhadap variabel citra tubuh. rerata citra tubuh remaja laki-laki. Rerata subjek remaja perempuan menunjukkan hasil 90,65 dan subjek laki-laki memiliki rerata citra tubuh sebesar 87,78. Hasil analisis tambahan untuk faktor lain dijabarkan dalam Tabel 2.

Hasil analisis tambahan menggunakan one way ANOVA untuk faktor usia, domisili, dan indeks massa tubuh (IMT) menunjukkan tidak ada perbedaan tingkat citra tubuh ditinjau dari faktor usia $(F=0,320 ; p=0,811)$, domisili $(F=0,851 ; p=0,467)$, dan IMT $(F=$ $0,980 ; p=0,377)$. Analisis tambahan mengenai waktu akses internet dalam sehari $(F=0,663 ; p=0,575)$, waktu akses 
Tabel 2.

Hasil Analisis Tambahan Menggunakan One Way ANOVA

\begin{tabular}{lcc}
\hline \multicolumn{1}{c}{ Faktor } & $\boldsymbol{F}$ & $\boldsymbol{p}$ \\
\hline Usia & 0,320 & 0,811 \\
Domisili & 0,851 & 0,467 \\
Indeks Massa Tubuh (IMT) & 0,980 & 0,377 \\
Waktu akses internet dalam sehari & 0,663 & 0,575 \\
Waktu akses instagram dalam sehari & 0,609 & 0,610 \\
Jenis akun yang paling banyak diikuti & 1,402 & 0,173 \\
\hline
\end{tabular}

Instagram dalam sehari $(F=0,609 ; p=$ $0,610)$, dan jenis akun yang paling banyak diikuti $(F=1,402 ; p=0,173)$ juga tidak menunjukkan adanya perbedaan signifikan pada citra tubuh.

\section{Diskusi}

Citra tubuh berhubungan dengan persepsi, perasaan, dan pikiran seseorang mengenai tubuhnya, dan biasanya dikonseptualisasikan dengan menggabungkan estimasi ukuran tubuh, evaluasi ketertarikan tubuh, dan emosi terkait bentuk dan ukuran tubuh (Muth \& Cash, dalam Grogan, 2006). Tinggi rendahnya citra tubuh disebabkan oleh banyak faktor, salah satunya adalah dukungan sosial. Hasil analisis korelasi pada penelitian ini membuktikan bahwa terdapat hubungan positif antara dukungan sosial dalam konteks online dan citra tubuh pada remaja pengguna media sosial Instagram dengan tingkat kontribusi sebesar $6,8 \%$.

Hasil ini sesuai dengan penemuanoleh Larson, Quinnel, Retka, Webb, danWilliams (2009) bahwa ada hubunganpositif antara dukungan sosial dengancitra tubuh. Studi eksperimen yang dilakukan Spice dan Spangler (dalam Borzekowski \&amp; Bayer, 2005) juga menunjukkan bahwa remaja perempuan yang cenderung tidak puas dengan tubuhnya dan kurang menerima dukungansosial secara signifikan mengalami peningkatan ketidakpuasan tubuh, perilaku diet, dan gejala bulimia jika dibandingkan yang lebih puas dengan bentuk tubuhnya serta menerima dukungan sosial.

Penelitian ini lebih berfokus pada dukungan sosial online karena citra tubuh remaja juga dipengaruhi oleh faktor paparan media sosial (Tiggeman \& Slater, 2013). Konten yang dilihat remaja dalam media sosial Instagram meningkatkan keinginan untuk memiliki bentuk fisik ideal. Keinginan untuk memiliki tubuh ideal sebagai dampak dari paparan media sosial Instagram muncul karena adanya proses perbandingan sosial. Perbandingan sosial adalah perbandingan yang dilakukan oleh individu dengan target yang dirasa mirip dengan dirinya (Brown \& Tiggemann, 2016).

Penelitian pada remaja pengguna media sosial Facebook menyatakan bahwa partisipan penelitian sering membandingkan penampilannya dengan teman, teman dekat, dan selebritis, tetapi mereka jarang membandingkan penampilan dengan keluarganya (Fardouly \& Vartanian, 2015). Terlebih lagi pada media sosial Instagram yang lebih banyak memiliki konten yang mendorong terjadinya perbandingan sosial. Media sosial ini berfokus pada konten multimedia seperti foto dan video personal penggunanya. Konten tersebut mau tidak mau membuat satu pengguna melakukan perbandingan diri dengan 
pengguna lainnya (Ozimek \& Bierhoff, 2016). Selain itu, media sosial seperti Instagram menyajikan informasi yang dapat dikuantifikasi seperti jumlah likes dan followers sehingga mempermudah perbandingan (Appel, Crusius \& Gerlach, 2016).

Perbandingan sosial dapat memicu menurunnya citra tubuh seiring dengan meningkatnya ketidakpuasan terhadap bentuk tubuh remaja (Rodgers, McLean, \& Paxton, 2015). Oleh karena itu, adanya dukungan sosial dapat membantu remaja mengatasi stres atau kehilangan kepercayaan diri karena citra tubuh yang buruk, meskipun berdasarkan penelitian ini hubungan antara keduanya sangat kecil. Rendahnya peran dukungan sosial online terhadap citra tubuh remaja pengguna Instagram disebabkan oleh hasil analisis korelasi menunjukkan dukungan sosial online hanya memiliki hubungan signifikan dengan dua dari lima dimensi citra tubuh, yaitu dimensi orientasi penampilan dan kecemasan kegemukan.

Studi terhadap remaja laki-laki dan perempuan di Belanda menemukan bahwa penggunaan media sosial meningkatkan orientasi terhadap penampilan (de Vries, Peter, Nikken, \& de Graaf, 2014). Penelitian tersebut menemukan bahwa terdapat kemungkinan jika remaja terpapar terhadap tekanan untuk berpenampilan lebih baik ketika mengakses media sosial seperti Instagram sehingga muncul sikap orientasi penampilan. Individu memiliki ketakutan bahwa penampilannya dievaluasi secara negatif oleh orang lain sehingga mereka mulai membentuk perilaku yang mencerminkan orientasi terhadap penampilan (Chang, Jarry, \& Kong, 2014). Dukungan sosial ditemukan memiliki peran terhadap ketakutan akan evaluasi negatif orang lain terhadap remaja (Teachman \& Allen, 2007). Seseorang yang mendapatkan dukungan positif dari orang-orang di sekitarnya cenderung lebih tidak mengkhawatirkan evaluasi negatif eksternal. Hingga saat ini belum ada penelitian yang menunjukkan bagaimana dinamika peran dukungan sosial terhadap ketakutan akan evaluasi negatif yang menimbulkan orientasi penampilan dalam konteks media sosial. Akan tetapi terdapat suatu studi yang kemungkinan dapat mengilustrasikan dinamika tersebut. Penelitian terhadap orang yang memiliki luka bakar menemukan bahwa dukungan sosial memiliki peran besar terhadap orientasi penampilan dengan mengakomodasi individu untuk mengutarakan pikiran dan perasaan mengenai orientasi terhadap penampilan (Hodder, Chur-Hansen, \& Parker, 2014).

Temuan bahwa dukungan sosial berhubungan dengan kecemasan kegemukan pada remaja sejalan dengan hasil penelitian Thompson, RussellMayhew, dan Saraceni (2012) yang menyatakan bahwa dukungan sosial positif berpengaruh terhadap penurunan kecemasan mengenai berat badan pada remaja. Paxton, Schutz, Wertheim, dan Muir (1999) menemukan bahwa sikap lingkungan sosial terhadap citra tubuh secara keseluruhan akan memprediksi bagaimana kepedulian remaja terhadap citra tubuhnya, termasuk di dalamnya kecemasan kegemukan. Apabila lingkungan di sekitar remaja memberikan dukungan yang positif, remaja akan merasa lebih percaya diri akan berat badannya. Pernyataan ini didukung oleh hasil penelitian McVey, Lieberman, Voorberg, Wardrope, dan Blackmore (2003) yang menunjukkan bahwa remaja yang semula memiliki kecemasan akan berat badannya ketika diberi intervensi berupa dukungan sosial dari teman sebaya cenderung meningkat kepercayaan dirinya dan lebih jarang untuk melakukan diet. 
Di samping itu, kurangnya peranan dukungan sosial online terhadap citra tubuh dapat disebabkan oleh rendahnya jumlah subjek yang memiliki indeks massa tubuh (IMT) dengan kategori overweight. Sebagian besar subjek memiliki IMT dengan kategori normal sehingga tidak memiliki masalah citra tubuh yang rendah yang menyebabkan tidak ada kebutuhan untuk mendapat dukungan sosial yang tinggi sehingga pada penelitian ini kebutuhan dukungan sosial terhadap baik buruknya citra tubuh remaja tidak banyak terungkap.

Selanjutnya, hasil analisis pada faktor jenis kelamin menunjukkan ada perbedaan yang signifikan pada citra tubuh remaja laki-laki dibandingkan remaja perempuan. Teori dan penelitian terdahulu menyatakan bahwa remaja perempuan memiliki citra tubuh yang lebih rendah dari remaja laki-laki (Suka et al., 2006; Olds, 2010; Santrock, 2011; Moy, 2015). Namun, hasil penelitian ini justru menunjukkan hasil yang bertolak belakang karena rerata antara remaja lakilaki dan perempuan menyatakan remaja perempuan memiliki citra tubuh yang lebih tinggi.

Mengenai hal tersebut, Wichstrom (dalam Bearman, et al., 2006) menyatakan dukungan dapat menjadi faktor risiko dalam perkembangan ketidakpuasan terhadap tubuh. Remaja yang mendapatkan dukungan sosial tak bersyarat dari jaringan sosialnya cenderung lebih puas dengan bentuk tubuh mereka. Pernyataan tersebut didukung oleh hasil studi oleh Stice \& Whitenton (dalam Bearman, et al., 2006) bahwa dukungan sosial secara signifikan berkaitan dengan peningkatan kepuasan terhadap bentuk tubuh remaja perempuan. Hal itu sesuai dengan hasil dari penelitian karena hasil perbandingan rerata dukungan sosial online pada remaja perempuan lebih tinggi dibandingkan remaja laki-laki. Oleh karena itu, pada penelitian ini kepuasan citra tubuh pada remaja perempuan menjadi lebih tinggi jika dibandingkan remaja laki-laki.

Pada faktor usia, hasil analisis pada penelitian ini menunjukkan tidak ada perbedaan citra tubuh berdasarkan perbedaan usia. Rentang usia subjek pada penelitian ini antara 15-18 tahun. Rentang usia tersebut masih dalam kategori remaja. Santrock (2011) menyatakan bahwa perhatian terhadap citra tubuh paling tinggi dialami pada masa remaja. Hal tersebut terjadi karena remaja mengalami perubahan signifikan pada tubuh mereka yang dikenal dengan pubertas. Oleh karena itu, ketiadaan perbedaan citra tubuh berdasarkan usia disebabkan oleh subjek penelitian yang masih dalam satu kategori yaitu remaja sehingga tidak ada subjek yang memiliki perbedaan tahap perkembangan.

Analisis tambahan terkait domisili menemukan bahwa tidak ada perbedaan yang signifikan pada citra tubuh remaja berdasarkan perbedaan domisili. Domisili termasuk dalam faktor sosiokultural yang dapat berkaitan dengan tingkat citra tubuh remaja. Budaya atau sub-budaya yang berlaku di sekitar tempat tinggal remaja memiliki norma mengenai sesuatu yang dianggap indah dan seberapa penting memiliki bentuk tubuh tertentu. Norma mengenai bentuk tubuh yang baik dapat tersebar melalui media, seperti televisi, radio, majalah, film, dan internet.

Sementara itu, sebuah penelitian menyatakan bahwa terdapat perbedaan citra tubuh antara remaja perempuan di wilayah kota metropolitan dan pedesaan di Turki. Remaja perempuan yang tinggal di wilayah metropolitan memiliki citra tubuh yang lebih rendah dibandingkan dengan remaja yang tinggal di wilayah perdesaan karena remaja di kota metropolitan lebih rentan terpapar dengan hal-hal yang mendorong 
keinginan memiliki tubuh ideal serta memiliki tingkat pendidikan yang lebih tinggi (Karsli \& Karsli, 2015). Dalam penelitian ini, tiga dari empat wilayah tempat tinggal subjek merupakan kota metropolitan, yaitu DKI Jakarta, Bandung, dan Surabaya merupakan kota metropolitan (Bappenas, 2014), sedangkan DI Yogyakarta bukan wilayah kota metropolitan tetapi termasuk dalam kategori kota besar.

Paparan di atas dapat menjelaskan alasan terkait tidak ada perbedaan signfikan pada keempat wilayah target penelitian. Subjek remaja dari asal domisili yang berbeda memiliki kesamaan latar belakang budaya mengenai bentuk tubuh ideal yang dianggap baik serta subjek di wilayah metropolitan maupun di kota besar memiliki kesamaan yaitu terkena paparan internet karena keempat wilayah tersebut adalah wilayah-wilayah di Pulau Jawa dengan jumlah pengguna internet yang tinggi berdasarkan survei Asosiasi Penyelenggara Jasa Internet Indonesia (APJII) pada tahun 2016. Selain kesamaan paparan internet, remaja dari keempat wilayah tersebut memiliki tingkat pendidikan yang sama yaitu siswa dan siswi SMA/sederajat. Oleh karena itu, peneliti menarik kesimpulan domisili tidak dapat membedakan citra tubuh karena semua subjek memiliki norma yang sama mengenai bentuk tubuh yang indah, kesamaan terpapar oleh internet, dan memiliki tingkat pendidikan yang sama baik di kota-kota metropolitan (DKI Jakarta, Bandung, dan Surabaya) maupun di kota besar (DI Yogyakarta).

Dalam penelitian ini, IMT diukur sebagai indikator objektif terkait ukuran tubuh subjek. Hasil analisis tidak menemukan adanya perbedaan signifikan pada citra tubuh remaja ditinjau dari perbedaan IMT. Hasil serupa juga ditemukan pada penelitian oleh Matz, Foster, Faith, dan Waden (2002) yang menyatakan bahwa tidak terdapat hubungan yang signifikan antara IMT dengan citra tubuh pada wanita obesitas. Penelitian pada remaja yang dilakukan oleh Nainggolan (2013) pun menyatakan distorsi terhadap citra tubuh remaja tidak dipengaruhi oleh IMT. Hal ini dapat disebabkan oleh kesalahan persepsi remaja mengenai berat badan mereka yang sesungguhnya (Isomaa, Isomaa, Marttunen, Kaltiala-Heino \& Björkqvist, 2011). Remaja dapat menilai bahwa dirinya kekurangan berat badan (underweight) atau kelebihan berat badan (overweight) tanpa didasari oleh IMT. Penemuan tersebut didukung oleh penelitian terhadap remaja di Turki yang menemukan bahwa faktor lain seperti harga diri, persepsi tubuh ideal, dan konsep fisik tubuh individu lebih berperan terhadap citra tubuh apabila dibandingkan dengan IMT (Canpolat, Orsel, Akdemir \& Ozbay, 2005). Dapat disimpulkan bahwa remaja tidak membangun citra tubuh berdasarkan data objektif seperti IMT.

Data subjek penelitian ini menunjukkan tidak ada remaja yang masuk dalam kategori sangat kurus. Sebagian besar remaja subjek penelitian memiliki IMT dalam kategori normal, sedangkan sebagian kecil subjek masuk dalam kategori kelebihan berat badan (overweight) dan hanya satu yang masuk dalam kategori kurus. Walaupun tidak ada perbedaan yang signifikan antara citra tubuh dan IMT $(p>0,05)$, data analisis deskriptif menunjukkan remaja dengan kategori IMT kurus dan overweight memiliki citra tubuh yang lebih rendah daripada remaja dengan IMT normal. Hasil tersebut menunjukkan IMT berbanding lurus dengan citra tubuh tetapi tidak signifikan dalam penelitian ini.

Analisis tambahan selanjutnya terkait waktu akses internet remaja dalam 
satu hari. Remaja pada subjek penelitian ini lebih banyak mengakses internet selama 4-8 jam dalam satu hari. Hootsuite $\mathcal{E}$ We Are Social (2017) pun menyatakan hasil survei rata-rata penggunaan internet masyarakat Indonesia dalam satu hari adalah selama 4 jam 47 menit. Selama rentang waktu tersebut banyak yang dapat dilakukan ketika mengakses internet. Menurut APJII (2016), alasan utama seseorang mengakses internet yaitu untuk mencari informasi, bersosialisasi, mencari hiburan, mencari referensi terkait suatu pekerjaan, mengisi waktu luang, mencari hal-hal terkait pendidikan, dan berbisnis, berdagang, atau mencari barang di internet.

Di samping waktu akses penggunaan internet, data menunjukkan waktu akses media sosial Instagram pada remaja subjek penelitian. Waktu akses Instagram terbanyak adalah kurang dari 3 jam dalam satu hari. Hasil tersebut mendekati hasil survei mengenai waktu akses media sosial bahwa pengguna internet di Indonesia mengakses media sosial dalam waktu 3 jam 16 menit dalam satu hari (Hootsuite \& We Are Social, 2017). Kemudian, menurut data terkini yang disajikan oleh Hootsuite \& We Are Social (2017), media sosial Instagram menempati urutan ketiga dari media sosial yang paling banyak diakses di Indonesia setelah Youtube (49\%) dan Facebook (48\%). Di samping itu, survei terbaru dari Tirto.id (2017) menyatakan bahwa responden berusia 7-21 tahun di Jawa dan Bali paling banyak menggunakan media sosial Instagram dalam mengakses informasi.

Masih mengenai waktu akses internet dan media sosial Instagram, pada penelitian ini tidak ditemukan adanya perbedaan citra tubuh berdasarkan rentang waktu para remaja mengakses internet dan media sosial Instagram. Dalam sebuah penelitian dinyatakan bahwa pada responden yang menggunakan internet secara luas seperti untuk mengakses YouTube, Google, atau Messenger tidak memiliki hubungan dengan perhatian pada citra tubuh, berbeda dengan responden yang akses internet untuk mengakses Facebook dan MySpace karena terdapat interaktivitas di dalamnya (Tiggemann \& Slater, 2013). Hasil penelitian pada remaja perempuan tersebut menunjukkan bahwa akses internet secara umum tidak memiliki hubungan dengan citra tubuh, kecuali pada situs atau media sosial tertentu, terutama Instagram yang kontennya sarat dengan figur tubuh ideal jika mengikuti akun-akun tertentu.

Sementara itu, analisis waktu akses media sosial Instagram dalam satu hari juga tidak dapat membedakan tingkat citra tubuh pada remaja usia 15-18 tahun. Hal ini dapat disebabkan oleh jenis akun yang paling banyak diikuti (difollow) dalam penggunaan Instagram. Hasil penelitian menunjukkan remaja paling dominan mengikuti akun hiburan yaitu sebanyak 22,55\% dari subjek, remaja yang mengikuti akun public figure atau selebgram sebanyak 20\%, sedangkan remaja yang mengikuti akun yang berhubungan dengan penampilan, yaitu akun kecantikan hanya sebesar $6,38 \%$.

Jika waktu akses Instagram dan jenis akun yang paling banyak diikuti tidak dapat membedakan tingkat citra tubuh seseorang, maka konten yang dilihat subjek saat menggunakan Instagram kemungkinan bukanlah konten yang berhubungan dengan penampilan dan menunjukkan figur tubuh ideal atau yang dewasa ini sering disebut dengan 'body goals'. Mengenai hal ini, Hendrickse (2016) dalam penelitiannya pada remaja perempuan tidak menemukan hubungan langsung antara penggunaan media sosial Instagram. Meskipun demikian, dinyatakan oleh Hendrickse (2016) bahwa 
Instagram akan berdampak negatif pada citra tubuh ketika remaja terpapar konten yang mendorong munculnya perbandingan penampilan (Hendrickse, 2016). Oleh sebab itu, waktu akses Instagram dan jenis akun yang diikuti tidak dapat membedakan citra tubuh karena tidak dapat dipastikan akun-akun tersebut menampilkan konten yang mendorong terjadinya perbandingan penampilan.

\section{Kesimpulan}

Disimpulkan bahwa terdapat hubungan positif antara dukungan sosial online dengan citra tubuh pada remaja usia SMA pengguna media sosial Instagram di wilayah DI Yogyakarta, DKI Jakarta, Bandung, dan Surabaya. Artinya, semakin tinggi dukungan sosial online yang didapatkan oleh remaja, semakin tinggi pula tingkat citra tubuh yang dimiliki remaja. Sebaliknya, semakin rendah tingkat dukungan sosial online, semakin rendah tingkat citra tubuh remaja. Akan tetapi, tingkat korelasi yang rendah sehingga sumbangan efektif variabel dukungan sosial online terhadap citra tubuh sangat kecil, yaitu sebesar 6,8\%. Hal ini mengindikasikan bahwa terdapat faktor-faktor lain yang tidak diteliti dan memiliki sumbangan efektif yang lebih besar pada citra tubuh remaja.

Kesimpulan lain dari hasil penelitian yaitu remaja usia SMA di wilayah DI Yogyakarta, DKI Jakarta, Bandung, dan Surabaya sebagian besar memiliki tingkat dukungan sosial online pada tingkat sedang, sama halnya dengan citra tubuh remaja tersebut sebagian besar dalam kategori sedang. Selain itu, hasil penelitian ini menunjukkan adanya perbedaan citra tubuh ditinjau dari perbedaan jenis kelamin. Namun, tidak terdapat perbedaan citra tubuh ditinjau dari usia, domisili, indeks massa tubuh
(IMT), waktu akses internet dalam satu hari, waktu akses Instagram dalam satu hari, serta jenis akun yang paling banyak diikuti dalam menggunakan media sosial Instagram.

\section{Saran}

Keterbatasan jumlah subjek, rentang usia, dan domisili subjek menyebabkan hasil penelitian ini tidak dapat digeneralisasikan. Maka disarankan penelitian selanjutnya mencakup jumlah subjek yang lebih banyak, melihat pada tahap perkembangan yang berbeda-beda, serta mempertimbangkan unsur demografis lainnya sehingga hasil penelitian dapat digeneralisasikan.

Dukungan sosial online dan citra tubuh memiliki korelasi. Namun, sumbangan efektifnya sangat kecil dan hanya berlaku untuk dimensi tertentu. Oleh karena itu, peneliti menyarankan penelitian selanjutnya juga meneliti faktor-faktor lain dari variabel citra tubuh sehingga kajian mengenai variabel citra tubuh dapat diketahui secara menyeluruh. Selain itu, akan lebih baik jika subjek penelitian mencakup remaja yang memiliki kategori tubuh overweight berdasarkan IMT karena kebutuhan akan dukungan sosial online terhadap bagaimana remaja melihat citra tubuhnya akan lebih terlihat.

Saran selanjutnya, penelitian akan lebih baik apabila perbandingan sosial turut diukur sebagai variabel moderator sehingga akan terlihat perbedaan citra tubuh ketika tinggi rendahnya perbandingan sosial yang dilakukan remaja dapat diketahui.

\section{Kepustakaan}

Appel, H., Crusius, J., \& Gerlach, A. L. (2015). Social comparison, envy, and depression on Facebook: A study looking at the effects of high 
comparison standards on depressed individuals. Journal of Social and Clinical Psychology, 34(4), 277-289. doi: 10.1521/jscp.2015.34.4.277

Asberg, K. K., \& Wagaman, A. (2010). Emotion regulation abilities and perceived stress as predictors of negative body image and problematic eating behaviors in emerging adults. American Journal of Psychological Research, 6(1), 193217.

Asosiasi Penyelenggara Jasa Internet Indonesia (APJII). (2016). Statistik. http://www.apjii.or.id/survei (pada 1 Februari 2017)

Ata, R. N., Ludden, A. B., \& Lally, M. M. (2007). The effects of gender and family, friend, and media influences on eating behaviors and body image during adolescence. Journal of Youth and Adolescence, 36(8), 1024-1037. doi: 10.1007/s10964-006-9159-x

Bappenas. (2014). Buku III Agenda Pembangunan Wilayah - Rencana Pembangunan Jangka Menengah Nasional 2015-2019. Bappenas.

Bearman, S. K., Martinez, E., \& Stice, E. (2006). The skinny on body dissatisfaction: A longitudinal study of adolescent girls and boys. Journal of Youth and Adolescence, 35(2), 217229. doi: 10.1007\%2Fs10964-0059010-9

Borzekowski, D. L., \& Bayer, A. (2005, Juli). Body image and media use among adolescents. Adolescent Medicine Clinics, 16(2), 289-313. doi: 10.1016/j.admecli.2005.02.010

Brown, Z., \& Tiggemann, M. (2016). Attractive celebrity and peer images on Instagram: Effect on women's mood and body image. Body Image, 19, 37-43. doi: 10.1016/j.bodyim.2016.08.007
Canpolat, B. I., Orsel, S., Akdemir, A. \& Ozbay, M. H. (2005). The relationship between dieting and body image, body ideal, self-perception, and body mass index in Turkish adolescents. International Journal of Eating Disorders, 37(2), 150-155. doi: 10.1002/eat.20081

Cash, T. F., \& Smolak, L. (2011). Body image: A handbook of science, practice, and prevention. New York: The Guilford Press.

Chang, F. M., Jarry J. L., \& Kong M. A. (2014). Appearance investment mediates the association between fear of negative evaluation and dietary restraint. Body Image, 11(1), 72-76. doi: 10.1016/j.bodyim.2013.11.002

Chua, T. H., \& Chang, L. (2016). Follow me and like my beautiful selfies: Singapore teenage girls' engagement in self-presentation and peer comparison on social media. Computer Behavior, 55, 190-197. 10.1016/j.chb.2015.09.011

Cobb, N. J. (2007). Adolescence: Continuity, change, and diversity. New York: McGraw-Hill.

de Vries, D. A., Peter J., Nikken P., de Graaf H. (2014). The effect of social network site use on appearance investment and desire for cosmetic surgery among adolescent boys and girls. Sex Roles: A Journal of Research, 71(9-10), 283-295. doi: 10.1007/s11199-014-0412-6

Fardouly, J., \& Vartanian, L. R. (2015). Negative comparisons about one's appearance mediate the relationship between Facebook usage and body image concerns. Body Image, 12, 8288. doi: 10.1016/j.bodyim.2014.10.004

Fitriani, A. (2014). Hubungan antara kesepian dan dukungan sosial terhadap kepercayaan interpersonal pada remaja 
pengguna situs jejaring sosial (Tesis tidak dipublikasikan). Universitas Gadjah Mada, Yogyakarta.

Fox, J., \& Vendernia, M. A. (2016). Selective self-presentation and social comparison through photographs on social networking sites. Cyberpsychology, Behavior, and Social Networking, 19(10), 593-600. doi: 10.1089/cyber.2016.0248

Ghaznavi, J., \& Taylor, L. D. (2015). Bones, body parts, and sex appeal: An analysis of \#thinspiration images on popular social media. Body Image, 14, 54-61. doi: 10.1016/j.bodyim.2015.03.006

Grogan, S. (2006). Body image and health: Contemporary perspective. Journal of Health Psychology, 11(4), 523-530. doi: $\underline{10.1177 / 1359105306065013}$

Harper, B., \& Tiggemann, M. (2008). The effect of thin ideal media images on women's self-objectification, mood, and body image. Sex Roles: A Journal of Research, 58(9-10), 649-657. doi: 10.1007/s11199-007-9379-x

Hendrickse, J. A. (2016). Appearance-related comparisons mediate the relationship between instagram use and body image concerns (Tesis tidak dipublikasikan). Florida State University, Florida.

Hodder, K., Chur-Hansen, A., \& Parker, A. (2014). A thematic study of the role of social support in the body image of burn survivors. Health Psychology Research, 2(1), 21-24. doi: 10.4081\%2Fhpr.2014.1196.

Hootsuite \& We Are Social. (2017). Digital in 2017: Southeast Asia. Hootsuite \& We Are Social.

Isomaa, R., Isomaa, A., Marttunen, M., Kaltiala-Heino, R. \& Björkqvist, K. (2011). Longitudinal concomitants of incorrect weight perception in female and male adolescents. Body
Image, $8(1), \quad 58-63 . \quad$ doi: 10.1016/j.bodyim.2010.11.005

Karsli, Y., \& Karsli, T. A. (2015). Media effects on body image and eating attitudes od the women living in metropolitan and rural areas in Turkish population. Procedia - Social and Behavioral Sciences, 205, 99-102. doi: 10.1016/j.sbspro.2015.09.030

Kurniawan, M. Y. (2014). Hubungan persepsi tubuh dengan gangguan makan pada mahasiswa. Naskah tidak dipublikasikan. Bogor: Fakultas Ekologi Manusia, Institut Pertanian Bogor

Larson, E., Quinnell, E., Retka, J., Webb, A., \& Williams, A. (2009). The drive for thinnes: The relationship between social support, body image, and eating habits. Diakses melalui https://pdfs.semanticscholar.org/fe8c 186c329093e7aba4c47386bdf6f804031 c6e7.pdf

Mattson, M., \& Hall, J. G. (2011). Linking health communication with social support. Dubuque, IA: Kendall Hunt Publishing Company.

Matz, P. E., Foster, G. D., Faith, M. S., \& Wadden, T. A. (2002). Correlates of body image dissatisfaction among overweight women seeking weight loss. Journal of Consulting and Clinical Psychology, 70(4), 1040-1044. doi: 10.1037//0022-006X.70.4.1040

McVey, G. L., Lieberman, M., Voorberg, N., Wardrope, D., Blackmore, E. (2003). School-based peer support groups: a new approach to the prevention of disordered eating. Eating Disorders: The Journal of Treatment and Prevention, 11(3), 169185. doi: $10.1080 / 10640260390218297$.

Morry, M. M., \& Staska, S. L. (2001). Magazine exposure: Internalization, self-objectification, eating attitudes, and body satisfaction in male and female university students. Canadian 
Journal of Behavioural Science, 33(4), 269-279. doi: $\underline{10.1037 / \mathrm{h} 0087148}$

Moy, G. (2015). Media, family, and peer influence on children's body image (Tesis tidak dipublikasikan). University of New Jersey, New Jersey.

Nainggolan, J. A. (2013). Hubungan citra tubuh, aktifitas fisik, dan pola konsumsi dengan status gizi (IMT/U) pada remaja putri di SMP Makarya Kebayoran Lama Jakarta Selatan tahun 2013 (Skripsi tidak dipublikasikan). Universitas Indonesia, Depok.

Olds, M. S. (2010). The relationship between body image and body mass index in attendees at a health fair. Dayton, Ohio: Wright State University.

Ozimek, P., \& Bierhoff, H. W. (2016). Facebook use depending on age: The influence of social comparisons. Computers in Human Behavior, 61, 271-279.

doi: 10.1016/i.chb.2016.03.034

Paxton, S. J., Schutz, H. K., Wertheim, E. H., \& Muir, S. L. (1999). Friendship clique and peer influences on body image concerns, dietary restraint, extreme weight-loss behaviors, and binge eating in adolescent girls. Journal of Abnormal Psychology, 108(2), 255-266. 10.1037/0021$\underline{843 X .108 .2 .255}$

Ridgway, J., \& Clayton, R. (2016). Instagram unfiltered: Exploring associations od body image satisfaction, Instagram \#selfie posting, and negative romantic relationship outcomes. Cyberpsychology, Behavior, and Social Networking, 19(1), 2-7. doi: 10.1089/cyber.2015.0433

Rodgers, R. F., McLean, S. A., \& Paxton, S. J. (2015). Longitudinal relationships among internalization of the media ideal, peer social comparison, and body dissatisfaction: Implications for the tripartite influence model. Developmental Psychology, 51(5), 706713. doi: $10.1037 /$ dev0000013

Santrock, J. W. (2011). Lifespan development (Edisi ketiga belas). New York: McGraw-Hill.

Suka, M., Sugimori, H., Yoshida, K., Kanayama, H., Sekine, M., Yamagami, T., Kagamimori, S. (2006). Body image, body satisfaction, and dieting behavior in Japanese preadolescents: The Toyama birth cohort study. Environmental Health and Preventive Medicine, 11(1), 24-30. doi: 10.1007\%2FBF02898204

Suryani, C. (2014). Kepercayaan interpersonal sebagai mediator dari hubungan dukungan sosial terhadap keterbukaan diri remaja dalam menggunakan situs jejaring sosial (Tesis tidak dipublikasikan). Universitas Gadjah Mada, Yogyakarta.

Tajalli, P., Sobhi, A., \& Ganbaripanah, A. (2010). The relationship between daily hassles and social support on mental health of university students. Procedia Social and Behavioral Sciences, 5, 99-103. doi: 10.1016/j.sbspro.2010.07.058

Teachman, B. A. \& Allen, J. P. (2007). Development of social anxiety: social interaction predictors of implicit and explicit fear of negative evaluation. Journal of Abnormal Child Psychology, 35(1), 63-78. doi: 10.1007/s10802-006-9084-1

Thompson, C., Russell-Mayhew, S., \& Saraceni, R. (2012). Evaluating the effects of a peer-support model: Reducing negative body esteem and disordered eating attitudes and behaviours in grade eight girls. Eating Disorders: The Journal of Treatment $\mathcal{E}$ Prevention, 20(2), 113- 
126.

$\underline{10.1080 / 10640266.2012 .653946}$

Tiggemann, M., \& Slater, A. (2013).

NetGirls: The Intenet, Facebook, and body image concern in adolescent girls. International Journal of Eating Disorders, 46(6), 630-633. doi: $\underline{10.1002 / \text { eat.22141 }}$

Tirto.id. (2017). Gen Z. Diakses melalui https://tirto.id/tirto-visual-reportmasa-depan-di-tangan-generasi-zctMM (pada Agustus 2017)

Tyler, S. (2016). Instagram: What makes you post?. Pepperdine Journal of Communication Research, 4(1), 30-39.
Webb, H. J., \& Zimmer-Gembeck, M. J. (2014). The role of friends and peers in adolescent body dissatifaction: A review and critique of 15 years of research. Journal of Research on Adolescence 24(4), 564-590. doi: $\underline{10.1111 / j o r a .12084}$ 